\title{
THE NEW MARRIED WOMEN'S CITIZENSHIP LAW
}

\author{
RICHARD W. FLOURNOY, Jr.
}

Since the passage of the Act of Congress of September 22, I922, ${ }^{1}$ "relative to the naturalization and citizenship of married women," many women have found themselves in a puzzling situation, some because they discovered that they could legally claim citizenship in two separate countries, and did not know which to choose; others, because they had no citizenship in any country. Such cases must necessarily continue and multiply unless the laws of most foreign countries are amended to accord with our law, or our law is changed. It seems worth while to consider the various provisions of our law which have given rise to this peculiar situation.

While, perhaps, most people have a distaste for reading statutes and prefer to have them served up in the form of paraphrases, if at all, the writer believes it to be desirable, when discussing a statute in a serious way, to have its exact phraseology constantly in view. The act in question governs the status of women of two classes: first, alien women who marry American citizens, and second, American women who marry aliens. The first category is covered by Sections I, 2, 5 and 6 of the Act which read as follows:

That the right of any woman to become a naturalized citizen of the United States shall not be denied or abridged because of her sex or because she is a married woman.

SEc. 2. That any woman who marries a citizen of the United States after the passage of this Act, or any woman whose husband is naturalized after the passage of this Act, shall not become a citizen of the United States by reason of such marriage or naturalization; but, if eligible to citizenship, she may be naturalized upon full and complete compliance with all requirements of the naturalization laws, with the following exceptions:

(a) No declaration of intention shall be required;

(b) In lieu of the five-year period of residence within the United States and the one-year period of residence within the State or Territory where the naturalization court is held, she shall have resided continuously in the United States, Hawaii, Alaska, or Porto Rico for at least one year immediately preceding the filing of the petition.

SEC. 5. That no woman whose husband is not eligible to citizenship shall be naturalized during the continuance of the marital status.

SEC. 6. That section I994 of the Revised Statutes and section 4 of the Expatriation Act of 1907 are repealed. Such repeal shall not terminate citizenship acquired or retained under either of such sections nor restore citizenship lost under section 4 of the Expatriation Act of 1907.

\footnotetext{
${ }_{42}^{1}$ Stat. at L. I02I, ch. 4II.
} 
Section I994 of the Revised Statutes, which has been repealed by the new statute, was taken from the Act of Congress of February Io, I855, and read as follows:

"Any woman who is now or may hereafter be married to a citizen of the United States, and who might herself be lawfully naturalized, shall be deemed a citizen."

Section 4 of the Act of March 2, I907, also repealed by the new law, provided for the retention of American citizenship by women of the class just mentioned, after termination of the marital relation. This provision was of relatively small importance, and will not be discussed in detail.

It is interesting to note that it was not until the year I855 that Congress passed a statute providing for acquisition of American citizenship by foreign-born women through their marriage to American citizens, and that this provision was limited to those who might themselves "be lawfully naturalized." According to the decisions of the courts this provision related to the racial qualification found in Section 2169 of the Revised Statutes, ${ }^{4}$ so that alien women did not acquire American citizenship through marriage unless they were "white persons" or persons of "African nativity" or "African descent." It is also important to observe, with reference to Section I of the recent Act of Congress, that there was no statute which specifically provided that the wife of an alien became a citizen of the United States through his naturalization. The courts held, however, that the Act of February Io, I855, covered such cases, it being the intention of Congress that the citizenship of the wife should "follow that of the husband, without the necessity of any application for naturalization on her part."

It is obvious, therefore, that the new law, which makes the citizenship of married women separate from that of their husbands, does not necessarily mean progress. On the contrary it seems to involve retrogression, a return to a state of affairs which existed prior to the year 1855, when Congress, for the purpose of remedying what was believed to be a defect in the common law, and of making the nationality laws of this country accord with those of most of the enlightened countries of the world, passed the Act providing for the naturalization of alien women through marriage.

Our own nationality law is based upon the common law of England, ${ }^{7}$ and, in passing the Act of February I0, 1855, Congress followed in

\footnotetext{
2 Io Stat. at L. 604.

${ }^{3} 34$ Stat. at L. 1228, 1229.

46 Stat. at L. 254, 256, amended by 18 Stat at L. 316, 318.

${ }^{5}$ Kelly v. Orven (I868, U. S.) 7 Wall. 496.

'Ibid.

${ }^{7}$ See Flournoy, Dual Nationality and Election (rg2r) 30 Yale Law JouRNar, $545,546$.
} 
the footsteps of the British Parliament, which in the year I844 had passed a similar act. ${ }^{8}$ On the other hand it may be recalled that the important change made in the British law of naturalization of $1870,{ }^{9}$ under which the right of expatriation was at last recognized, was directly due to the contention of this Government with regard to the status of persons of British origin naturalized in the United States. ${ }^{10}$

Both of the changes referred to go to prove that nations cannot live and act for themselves alone, and that mutual concessions and accommodations are necessary to the maintenance of harmonious international intercourse.

The slowness of the British to adopt the rule that the nationality of a married woman follows that of the husband is perhaps due to two causes: first, the insular position of England and the consequent fact that comparatively few cases arose in ancient times in which alien women married British subjects; and second, the conservative tendency of the British and their reluctance to change any rule which appears to be embedded in the common law. It was certainly not due to any theory that the "freedom of women" made it improper to require that their nationality should follow that of their husbands. On the contrary, the adoption of the rule that a married woman's citizenship follows that of her husband was almost contemporaneous with the adoption of more liberal laws concerning her property rights.

The rule in question seems to have been recognized from time immemorial in the continental countries of Europe. We find it set forth in the Code Napoleon ${ }^{11}$ but this was not its origin in France. According to Stoicesco," "the principle that the married woman takes the nationality of her husband is in France as old as law itself." This principle seems to have been recognized by the Roman law, although it is somewhat difficult to understand precisely what the Roman law on the subject was: first, because the Roman conception of citizenship differed from our own; and second, because there were various forms of marriage recognized by Roman law. While in early times Roman citizenship seems to have been limited, under very strict rules, to membership in certain Roman tribes, so that it involved something like a caste system, it was greatly changed with the development of jus gentium and the growth of the Empire, until in the second century, by an edict of Caracalla, it was extended to all free persons under the Roman sway. Although under the ancient Roman law the marriage of a Roman citizen to an alien woman did not confer Roman citizenship on her unless she belonged to one of the privileged classes to which the

${ }^{3} 7 \& 8$ Vict. c. 66 , sec. 16.

${ }^{2} 33$ \& 34 Vict. c. I4, secs. 3, 4, 6.

${ }^{10}$ See Flournoy, Naturalization and Expatriation (1922) 3I Y ALE LAw JourNat, 702,714 et seq.

${ }^{11}$ Arts. 12, 19.

"La Naturalisation en Droit Francais (1876) 212. 
conubium, or right of marriage, had been extended, special provision was made for cases of Romans marrying peregrinae under the mistaken belief that they were Roman citizens. It appears that where a child was born to such a union, and the father "proved cause of error," both wife and child were recognized as Roman citizens. ${ }^{13}$ Evidently the noble Roman youths did not like being limited in the choice of wives to the young women of their own restricted class, and found their Samnite and Etruscan neighbors more interesting. Their desire for more freedom in this matter may have been increased by the famous legend, heard since childhood, of "the rape of the Sabine women." The law in question may have been a sort of fiction to make it possible for them not only to choose wives outside of their own circle, but to have them placed on an equality with themselves. What the rule was during the middle period of Roman history, after the free marriages had come to replace the strict marriages of the early Roman law, it is not easy to determine. However, probably by the time Justinian's Digest was published, A. D. 533, the principle that an alien woman is naturalized through marriage to a citizen was generally recognized. ${ }^{14}$

The rule in question did not, of course, originate with the Roman law. No doubt it began in prehistoric times, with the origin of marriage and family law. While, in early times, most peoples probably had laws prohibiting intermarriage with members of foreign nations, as was the case with the Israelites, it is reasonable to suppose that, when more liberal principles were adopted, and marriage between members of different nations or tribes was recognized as valid, women, when they were thus married, were detached from their original nations or tribes and became members of the nations or tribes into which they married.

To return to the provisions of the Act of September 22, I922, it may be observed that the first provision of Section I,

"That the right of any woman to become a naturalized citizen of the United States shall not be denied or abridged because of her sex,"

was entirely unnecessary, since, undir the pre-existing law, there was no such denial or abridgment. Unmarried women were, under the old law, as free to become naturalized in their own right as they are under the new law. The courts have held, however, in recent years, that the wife of an alien could not obtain naturalization as a citizen of the United States in her own right.

The second section of the new Act, which provides that an alien woman does not acquire American citizenship by marrying an American citizen, or through the naturalization of her husband, was urged upon

\footnotetext{
${ }^{12}$ Gaius, I, 67 .

14 D. 50. I. 38. 3 has been cited in support of this view, but, upon examination, this passage seems to relate to domicile, rather than citizenship. The word used is incola, an inhabitant. I have been unable to find that the Digest contains any specific provision concerning the citizenship of married women.
} 
Congress upon the theory that the granting of the suffrage to women made it especially important to prevent alien women from becoming citizens unless they had proven to the satisfaction of courts that they were fitted for naturalization. Theoretically this seems to be the strongest argument advanced in favor of the new law, although, as a practical matter, it seems doubtful whether this change will materially improve the character of foreign-born women who wish to take advantage of the right to vote. Perhaps, in some cases, women unfit for voting may be denied citizenship, but it is believed that, as a general rule, the character and qualifications of the wives of aliens will be on a par with those of their husbands. This subject was discussed at some length in Congress on June 20, I922. ${ }^{15}$ Representative Siegel, although he was arguing in favor of the new bill, called attention to one fact, of great practical importance in the consideration of this question, and that is that Section 2 of the new law, which requires alien married women to obtain naturalization in their own right, will add very greatly to the number of naturalization cases which will have to be considered by our courts. He mentioned the fact that, under the old law, one Judge in New York was called upon to naturalize 15,000 persons in one month. It is hard to see how a Judge, with such an enormous number of cases to dispose of in a limited time, can give any satisfactory consideration to the question of the character of the applicants and their qualifications for citizenship. This will, of course, become still more difficult as a result of the new law.

The provision of Section 5 of the Act does not seem to be of much practical importance. It is interesting to note, however, that when this provision, which prohibits the naturalization of a woman whose husband is not eligible to citizenship, and the provision of Section 3, to the effect that an American woman loses her citizenship if she marries an alien who is ineligible to citizenship, that is, one who does not belong to the white race or the African race, are inconsistent with the supposed basic theory of the Act, namely, that the citizenship of a married woman should be entirely separate and distinct from the citizenship of her husband. Both of these provisions recognize the essential unity of husband and wife as constituting a single family. This point was brought up in Congress by Representative Kincheloe, who asked for an explanation, and wished to know why, to be consistent, the law should not contain a provision that an American man who marries an alien woman ineligible for citizenship should not thereby lose his American citizenship. Although Mr. Kincheloe repeatedly insisted upon an explanation, Representative Raker, who sponsored the bill, persistently declined to discuss the point. ${ }^{16}$

The provisions of the new Act have resulted in leaving numbers of

${ }^{15} 62$ CoNG. REC. 9048 et seq.

${ }^{10}$ Ibid. 9063,9064 . Mr. Denison first called attention to this defect. Ibid. 9057. 
alien women who have married American citizens without any citizenship whatsoever, since the nationality laws of the following countries specifically provide that women having their nationality lose it upon marrying aliens: Costa Rica, Cuba, Dominican Republic, Germany, Great Britain, Greece, Haiti, Latvia, Mexico, Nicaragua, Peru, Poland, Rumania, Spain, Sweden, Switzerland and Turkey. The laws of Argentina and a number of Latin American countries are silent upon this point, but it is believed that women of those countries lose their nationality upon marrying aliens. ${ }^{17}$

Fortunately for French women who marry American citizens, they do not lose their French nationality by such marriage, since the French law states that French women lose their original nationality by marrying aliens only in case they acquire the nationality of their husbands under the laws of their husbands' countries. This provision is found in Article Ig of the French Civil Code, as amended by the Act of June 26, r889. The original provision of the Code Napoleon made no exception in favor of French women who did not acquire the nationality of their alien husbands by marriage. The change was made by the Act of I889 for the purpose of preventing cases of no nationality from arising. Similar provisions are found in the laws of Belgium, China, Italy, Japan, Netherlands, Norway, Persia, Portugal, Russia, Salvador, Siam and Venezuela. Under the laws of Guatemala and Honduras, women of those countries who marry aliens do not lose their original nationality unless they become domiciled abroad.

As intermarriage between American citizens and British subjects is not uncommon, it has occurred in a number of cases that British women who have married American citizens subsequent to September 22, I922, have found themselves without either British or American nationality, and therefore unable to obtain a passport from either country. Also cases have arisen in which Americans who have married alien women have found that the latter, not being American citizens, are subject to exclusion under the Restrictive Immigration Act.

The provision of Section 6 of the new Act repealing not only Section I994 of the Revised Statutes, but also Section 4 of the Expatriation Act of 1907 , does not seem to require further discussion.

We will now consider the cases of American women who marry aliens. Sections 3, 4 and 7 of the Act of September 22, r922, read as follows:

SEC. 3. That a woman citizen of the United States shall not cease to be a citizen of the United States by reason of her marriage after the passage of this Act, unless she makes a formal renunciation of her citizenship before a court having jurisdiction over naturalization of aliens: Provided, That any woman citizen who marries an alien ineligible to citizenship shall cease to be a citizen of the United States. If

\footnotetext{
${ }^{27}$ For a very thorough discussion of the Argentine law upon this point, which seems to be based upon the old Spanish Law, see 2 Zeballos, $\mathrm{La}$ Nationalite (1914) 358 et seq.
} 
at the termination of the marital status she is a citizen of the United States she shall retain her citizenship regardless of her residence. If during the continuance of the marital status she resides continuously for two years in a foreign State of which her husband is a citizen or subject, or for five years continuously outside the United States, she shall thereafter be subject to the same presumption as is a naturalized citizen of the United States under the second paragraph of section 2 of the Act entitled "An Act in reference to the expatriation of citizens and their protection abroad," approved March 2, I907. Nothing herein shall be construed to repeal or amend the provisions of Revised Statutes I999 or of section 2 of the Expatriation Act of I907 with reference to expatriation.

Src. 4. That a woman who, before the passage of this Act, has lost her United States citizenship by reason of her marriage to an alien eligible for citizenship, may be naturalized as provided by section 2 of this Act: Provided, That no certificate of arrival shall be required to be filed with her petition if during the continuance of the marital status she shall have resided within the United States. After her naturalization she shall have the same citizenship status as if her marriage had taken place after the passage of this Act.

SEC. 7. That section 3 of the Expatriation Act of 1907 is repealed. Such repeal shall not restore citizenship lost under such section nor terminate citizenship resumed under such section. A woman who has resumed under such section citizenship lost by marriage shall, upon the passage of this Act, have for all purposes the same citizenship status as immediately preceding her marriage.

Unfortunately, legislation is not always characterized by consistency, and it was not until the passage of the Naturalization Act, $1870,{ }^{18}$ that the British Government recognized the loss of British nationality in cases of British women who married aliens. Our own country was even more tardy in admitting this principle, which was not definitely recognized by statute until the passage of the Expatriation Act of March 2, I907, Section 3 of which provided:

"That any American woman who marries a foreigner shall take the nationality of her husband."

Considering the discussion of the similar provision of Section I9 of the Code Napoleon in the works of various French writers on the law of nationality, it is remarkable that our own Government should have copied the error which was contained in the French law, namely, the provision to the effect that a native woman marrying an alien took the nationality of her husband. It is quite obvious, upon a moment's thought, that one country cannot by legislation make a woman a citizen of another country. The French law was construed to mean simply that the woman lost her French nationality, and a similar construction was placed upon the similar provision in our own law. It may be observed, in passing, that prior to the passage of the Act of March 2,

\footnotetext{
${ }^{13} 33$ \& 34 Vict. c. 14, sec. 10.
} 
1907, the courts had been divided as to the question whether an American woman lost her American nationality upon marrying an alien. The weight of authority seems to have been to the effect that she did lose her American citizenship if she left the United States and went with her husband to reside in his own country. ${ }^{10}$ Whether an American woman lost her citizenship by marriage to an alien in case they remained in the United States after marriage seems to have been an unsettled point. The case of Comitis v. Parkerson ${ }^{20}$ has been cited in support of the theory that such a woman did not lose her citizenship, but it is important to observe that this case did not arise until after the death of the alien husband when, even under the opposite theory, the widow might reasonably have been regarded as having resumed her original status. ${ }^{21}$

Sections 3 and 7 of the new Act abolished the principle established by Section 3 of the Act of 1907 , and resulted in a reversion to the old common law rule that a woman did not lose her nationality by marrying an alien. ${ }^{212}$ The exception provided in the case of a woman who marries an alien ineligible to citizenship has already been mentioned, and attention has also been called to the apparent inconsistency of this exception with the principle which is supposed to underlie the Act. Section 3 of the new Act contains another provision of importance, to the effect that, when a woman married to an alien has resided for two years in the country of her husband's nationality, or for five years elsewhere outside of the United States, she shall thereafter be subject to the same presumption as is a naturalized citizen of the United States under the second paragraph of Section 2 of the Expatriation Act of March 2, I907. The presumption under the Act last mentioned ${ }^{22}$ is that the person concerned has "ceased to be an American citizen," but it also provides" "that such presumption may be overcome on the presentation of satisfactory evidence to a diplomatic or consular officer of the United States, under such rules and regulations as the Department of State may prescribe." The new law does not state whether a married woman who has brought upon herself the presumption of loss

See Ruckgaber v. Moore (1900, C. C. E. D. N. Y.) 104 Fed. 947.

${ }^{20}$ (I893, C. C. E. D. La.) 156 Fed. 556.

${ }^{27}$ For a discussion of the cases bearing upon this subject, see Van Dyne, Citizenship of the United States (1904) 127, and the Citizenship Board Report of Igo6, House Document 326, 59th Congress, 2d Sess., I50 et seq.

21a It will be noted, however, that an American woman marrying an alien may divest herself of her American citizenship, under the new law, by "making a formal renunciation of her citizenship before a court having jurisdiction over naturalization of aliens." Query: (I) Is it necessary for her to appear personally in court to make the renunciation? (2) If abroad, can she not cast off her American citizenship under Section 2, Act of March 2, 1907, by taking a foreign oath of allegiance?

2 Sec. 2.

Is Ibid. 
of citizenship may overcome such presumption, but the natural inference seems to be that she may. It is not clear, however, what rules should be prescribed for overcoming the presumption in a case of this kind, since it is reasonable to suppose that in most cases the married woman will be found to be residing abroad simply because her husband has his residence abroad.

Representative Rogers, when the present Act was under discussion in the House of Representatives, proposed an amendment to the effect that an American woman who married an alien should lose her American citizenship as soon as she should have ceased to reside in the United States, but this amendment was not adopted.24

Section 4 of the new Act makes provision for the naturalization of an American woman who lost her citizenship under the old law through marriage to an alien, and Section 7 specifically repeals Section 3 of the Act of 1907. Section 7 goes further and provides that the repeal of Section 3 of the old Act "shall not restore citizenship lost under such section nor terminate citizenship resumed under such section."

As a result of Section 3 of the new Act an American woman who has married a British subject remains an American citizen, although she also becomes a British subject under British law. Under the laws of the following countries, in addition to Great Britain, alien women marrying nationals thereof acquire the nationality of their husbands: Austria, Belgium, China, Colombia, Costa Rica, Cuba, Denmark, Dominican Republic, France, Germany, Greece, Hungary, Haiti, Italy, Japan, Latvia, Mexico, Netherlands, Norway, Peru, Persia, Poland, Portugal, Rumania, Russia, Siam, Spain, Sweden and Venezuela. As under Swiss law an alien woman is naturalized by the naturalization of her husband as a Swiss national, it seems likely that an alien woman becomes Swiss by marrying a Swiss national. While the laws of Argentina and several other Latin American countries contain no specific provision in regard to this matter, it seems likely that their laws are similar to the Spanish law, as in the case of nationals of those countries marrying aliens.

Cases have arisen in which American women who have married citizens of foreign countries since the passage of the new law have obtained American passports, in order to accompany their husbands abroad, and have been refused visas by consular officers of the countries to which their husbands belonged, because under the laws of those countries they are considered to be citizens or subjects thereof. When such a woman is residing in a foreign country and finds herself in need of protection she may be puzzled to decide whether she should call upon the United States or the country of her husband's nationality for protection. It will be especially important for her to decide this question in case she is residing in a country in which extraterritorial juris-

\footnotetext{
" 62 Cong. Rec. 9063, 9064.
} 
diction exists. It will hardly be proper for her to attempt to place herself under the protection of two countries.

Under Section 3 of the Act of 1907 an American-born widow of an alien could readily recover her American citizenship, if residing abroad, by registering within a year with an American consul, or by returning to the United States to reside. If residing in this country at the termination of the marital relation she resumed her citizenship merely by continuing to reside here. Under the new law, although she may have been born and reared in this country, she is apparently required to go before a court and obtain naturalization, in order to recover her American nationality: ${ }^{25}$

Although, in the discussion of the new law in Congress many members took the opportunity to declare themselves publicly and emphatically in favor of "the right of our sisters" to have a status precisely similar to that of the men of the country, it is quite clear that the law did not really give them this. It also appears that, while some women may have gained by it, others have lost. In the discussion of the bill on the floor of the House of Representatives there was a failure to bring out two important points. The first is that, after all, a woman is not compelled to marry an alien. When she does decide, of her own free will, to marry an alien, because of natural affection or for any other reason, it is natural to assume that she realizes that marriage involves giving up some things in order to gain others. It clearly involves leaving her own family and joining herself to her husband, for the purpose of establishing a new family unit. It is hard to see why consistency does not also require her, if she marries an alien, to surrender voluntarily her former nationality and receive the nationality of her husband. The old rule of law that a married woman takes the nationality of her husband, although Great Britain and our own country were slow to recognize it, was based not upon theory, but upon simple facts of life and customs of people. It is hard to see how the new law can remain unchanged unless the character of the marital relation itself is to be radically changed. ${ }^{28}$

\footnotetext{
${ }^{2 x}$ It has been contended, however, that the repeal of Section 3, Act of March 2 , 1907 , restores the law as it was at the time of the passage of that Act, so that an American-born woman who married an alien after March 2, 1907 and was divorced or became a widow after Sept. 22, 1922, recovers her American citizenship by continuing or acquiring a residence in this country.

${ }^{28}$ Mr. Justice McKenna, in delivering the opinion of the Supreme Court in Mackenzie v. Hare (I9I5) 239 U. S. 299, 3II, 36 Sup. Ct. 106, 108, in which it was held that an American woman lost her American citizenship, under Section 3. Act of March 2, 1907, by marrying an alien, even though they had both continued to reside in this country, said:

"The identity of husband and wife is an ancient principle of our jurisprudence. It was neither accidental nor arbitrary and worked in many instances for her protection. There has been, it is true, much relaxation of it but in its retention as in its origin it is determined by their intimate relation and unity of interests, and this relation and unity may make it of public concern in many
} 
Another important consideration is the question as to how the new law can be made to harmonize with the conflicting laws of other countries. As stated above, this cannot possibly be done unless most of the countries of the world change their laws to make them accord with our own, or we change our own law, at least to some extent, to make it accord with foreign laws. It has been suggested that the present difficulties arising under the new law could be obviated by changing the passport regulations. The idea seems to be that the regulations could be changed to permit of the issuance of passports to foreign women who have lost their former citizenship by marrying American citizens, but have not gained American citizenship. This would be impossible, since the $1 \mathrm{aw}^{27}$ permits of the issuance of passports only to citizens of the United States and persons owing allegiance to this country. ${ }^{28}$

It may be observed in passing that the new Act does not seem to have seriously affected the status of children. Those born in the United States are citizens of this country, under the provision of the Fourteenth Amendment to the Constitution, regardless of the nationality of their parents, while, as to children born abroad, Section 1993 of the Revised Statutes provides that they are American citizens if their "fathers" have that status and have resided in this country. It would seem, however, that, in view of the provision of Section I of the new Act children born without the United States of alien parents may be naturalized, under Section 5 of the Act of March 2, rgo7, by the naturalization of the mother, although the father may remain an alien. Section 5 provides for the naturalization of children through the naturalization of the "parent." It would seem that this word might be construed as applicable to either parent.

It seems questionable whether the majority of the women of this country really wanted the new law. Probably most of them knew nothing about it, although a number of women's organizations had announced themselves as being in favor of it, and had persuaded both political parties to make pronouncements in favor of it in their campaign platforms. While, no doubt, the women who promoted this law were in the minority, this was a strongly organized minority, and almost anything can be done by an organized minority when the majority is unorganized and more or less indifferent. The change in the law seems to have originated in a desire to make it possible for American women

instances to merge their identity, and give dominance to the husband. It has purpose, if not necessity, in purely domestic policy; it has greater purpose and it may be, necessity, in international policy. And this was the dictate of the act in controversy."

${ }^{2}$ U. S. Rev. Sts. 1874, sec. 4076; Act of May 30, I866 (14 Stat. at L. 54), as amended by the Act of June I4, 1902 (32 Stat. at L. 386).

${ }^{28}$ It has been suggested, however, that the names of alien wives of American citizens might be endorsed upon passports of the husbands to enable them to accompany the latter abroad, in cases where such women could not obtain foreign passports, and that such endorsement would not involve a violation of the law. 
to retain their American citizenship after marrying aliens. The provision in regard to the separate citizenship of foreign-born wives of American citizens seems to have been an after-thought. When the movement to change the law was begun much was said about the hardship and distress suffered by American women who, as in the Mackenzie case, ${ }^{29}$ lost their right to hold property in this country by marrying aliens, or who, during the recent war, had their property seized and were subjected to other restrictions because they were married to nationals of enemy countries. There is really little or nothing in these arguments, since it would be a simple matter to amend the laws of certain States to make it possible for American women married to aliens to hold real property therein, notwithstanding their loss of American citizenship, and it would be even simpler in time of war so to shape the laws as to avoid seizing the property of such persons. On the other hand, in time of war, it would certainly be extremely unfortunate for husbands and wives to have the status of nationals of opposing enemy countries. To any right-minded person this would be much more unfortunate than to suffer the temporary or even permanent loss of property rights.

The same reasons which brought about the passage of this Act will make it very difficult to have it repealed altogether, but perhaps a compromise may be reached. Such a compromise might consist in provisions to the effect that an American woman shall lose her American citizenship by marriage to an alien unless, within a prescribed period, she satisfies a court of naturalization that she intends to remain in the United States and that her husband intends to become naturalized as a citizen of this country, and that an alien woman shall not acquire American citizenship by marriage to an American until she establishes her residence in this country. Even these provisions would not altogether prevent conflicts with the laws of foreign countries from arising, but they would not be so serious as the conflicts arising out of the present law.

\footnotetext{
${ }^{2}$ Mackenzie v. Hare, supra note 26.
} 